\title{
Influence of the Residual Inductance of the Impulse Generator for the Generation of the Lightning Impulse Voltage
}

\author{
Satoshi Matsumoto Senior Member (Kyushu Institute of Technology)
}

Keywords: high voltage test, oscillating lightning impulse, impulse generator, residual inductance, waveform parameter

This paper describes the theoretical analysis of lightning impulse voltage waveform with an overshoot or oscillation caused by the residual inductance of the impulse generator. Figure 1 shows the equivalent circuit of the impulse generator. The lightning impulse waveform is expressed by the following formula;

$$
v_{\text {out }}(t)=A\left\{e^{-\alpha_{1} t}-e^{-\alpha_{2} t} \frac{\sin (\omega t+\theta)}{\sin \theta}\right\}
$$

where $A, \alpha_{1}, \alpha_{2}, \omega, \theta$ are constants, respectively. Those constants are given as follows;

$$
\begin{aligned}
& A=\frac{R_{0}}{\alpha_{2}-\alpha_{1}-\omega \cot \theta+R_{0} C_{0}\left(\alpha_{1}^{2}-\alpha_{2}^{2}+\omega^{2}+2 \alpha_{2} \omega \cot \theta\right)} \\
& \times \frac{V_{0}}{L_{s}} \\
& \alpha_{1}^{3}-a \alpha_{1}^{2}+b \alpha_{1}-c=0 \\
& 8 \alpha_{2}^{3}-8 a \alpha_{2}^{2}+2\left(a^{2}+b\right) \alpha_{2}+(c-a b)=0 \\
& \omega^{2}=3 \alpha_{2}^{2}-2 a \alpha_{2}+b \\
& \tan \theta=\frac{\omega}{\alpha_{2}-\alpha_{1}}
\end{aligned}
$$

where

$$
\left.\begin{array}{rl}
a & =\frac{L_{s}+R_{s} R_{0} C_{0}}{L_{s} R_{0} C_{0}} \\
b & =\frac{C_{s}\left(R_{s}+R_{0}\right)+R_{0} C_{0}}{L_{s} C_{s} R_{0} C_{0}} \\
c & =\frac{1}{L_{s} C_{s} R_{0} C_{0}}
\end{array}\right\}
$$

The wave form parameters such as the front time, tail time, peak value, oscillation frequency, overshoot voltage $\mathrm{k}$-factor and virtual origin are derived from this expression. Figure 2 shows the example of the lightning impulse voltage with the oscillation.

Some simulation results are summarized in Table 1. This formulation has many merits as shown bellows;

(1) The discussion on the definition of front time and tail time is possible by comparing the base curve (i.e. the lightning impulse without oscillation) and the overshoot.

(2) The formula can analyze the waveform shape and the overshot (i.e. k-factor and overshoot).

(3) The formula expresses the dominant oscillation as shown in Eq. (5).

(4) The formula shows the virtual origin analytically.

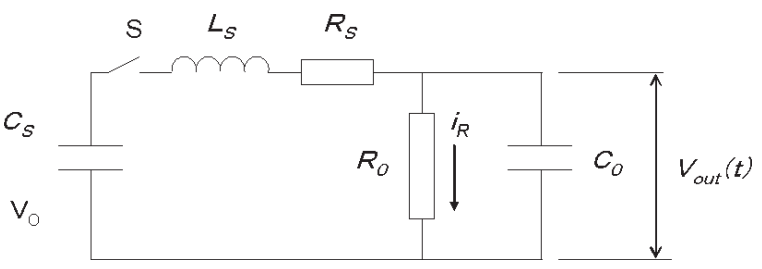

Fig. 1. Equivalent circuit for impulse generator

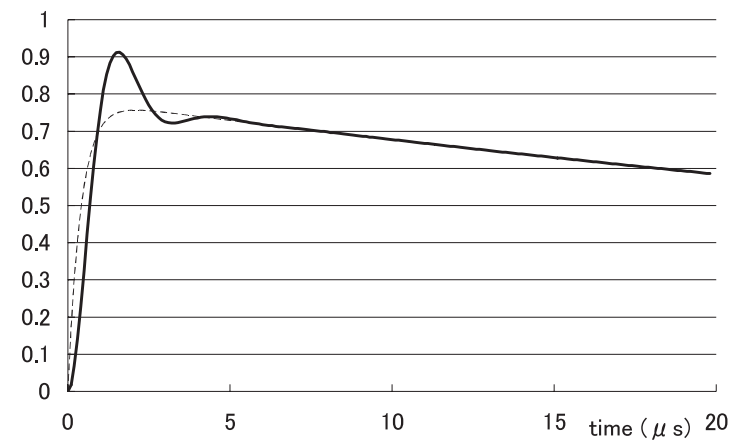

Fig. 2. Comparison with overshoot waveform and standard lightning $\left(L_{s}=50 \mu \mathrm{H}, \delta=20.7 \%\right.$, Type I-1)

Table 1. Summary of calculation results $\left(C_{S}=0.02 \mu \mathrm{F}\right.$, $C_{0}=5000 \mathrm{pF}, R_{S}=104 \Omega, R_{0}=2641 \Omega$ )

\begin{tabular}{|c|c|c|c|c|c|}
\hline \multirow{2}{*}{} & \multicolumn{5}{|c|}{ Residual inductance $L_{S}(\mu \mathrm{H})$} \\
\cline { 2 - 6 } & 0 & 20 & 50 & 100 & 200 \\
\hline$T_{1}(\mu \mathrm{s})$ & 1.2 & 0.87 & 1.13 & 1.50 & 2.06 \\
\hline$T_{2}(\mu \mathrm{s})$ & 50 & 45.9 & 36.6 & 29.9 & 24.1 \\
\hline$t_{m}(\mu \mathrm{s})$ & 2.09 & 1.26 & 1.56 & 2.07 & 2.84 \\
\hline$V_{p}(\mathrm{p} \mathrm{u})$ & 1 & 1.053 & 1.21 & 1.36 & 1.45 \\
\hline$\delta(\%)$ & - & 5.3 & 20.7 & 33.6 & 44.7 \\
\hline$f(\mathrm{k} \mathrm{Hz})$ & - & 387 & 318 & 239 & 174 \\
\hline$O^{\prime}, t_{0}(\mu \mathrm{s})$ & -0.22 & 0.01 & 0.11 & 0.11 & 0.31 \\
\hline$t_{30 \%}(\mu \mathrm{s})$ & 0.14 & 0.28 & 0.64 & 0.64 & 0.93 \\
\hline$t_{90 \%}(\mu \mathrm{s})$ & 0.86 & 0.80 & 1.54 & 1.54 & 2.16 \\
\hline$t_{50 \%}(\mu \mathrm{s})$ & 49.4 & 45.9 & 29.8 & 29.9 & 24.4 \\
\hline
\end{tabular}




\title{
インパルス電圧発生回路の残留インダクタンスが 雷インパルス電圧波形に及ぼす影響について
}

\author{
上級会員 松本 聡* \\ Influence of the Residual Inductance of the Impulse Generator for the Generation of \\ the Lightning Impulse Voltage \\ Satoshi Matsumoto*, Senior Member
}

This paper describes the theoretical analysis of lightning impulse voltage waveform with an overshoot or oscillation caused by the residual inductance of the impulse generator. The oscillating lightning impulse waveform is expressed by the following formula;

$$
v_{\text {out }}(t)=A\left\{e^{-\alpha_{1} t}-e^{-\alpha_{2} t} \frac{\sin (\omega t+\theta)}{\sin \theta}\right\}
$$

where $A, \alpha_{1}, \alpha_{2}, \omega, \theta$ are constants, respectively. The front time, time to half value, peak value, oscillation frequency, overshoot voltage k-factor and virtual origin are derived from this expression. Some simulation results show the following merits;

(1) The discussion on the definition of front time and tail time is possible by comparing with the base curve and overshoot.

(2) The formula can analyze the effect of the residual inductance of the test circuit and express the overshot (i.e. k-factor and overshoot).

(3) The formula can express the relationship between the oscillation frequency and the decay time.

(4) The discussion on the meaning of base curve and waveform parameters is possible based on the theoretical analysis.

キーワード : 高電圧試験, 振動性雷インパルス電圧, インパルス電圧発生装置, 残留インダクタンス, 波形パラメータ

Keywords: high voltage test, oscillating lightning impulse, impulse generator, residual inductance, waveform parameter

\section{1. まえがき}

従来，インパルス電圧発生器 $(\mathrm{IG})$ による雷インパルス 電圧波形は, いわゆる 2 組の指数関数の和として標準波形 が定義され，種々の解析がなされてきた ${ }^{(1) \sim(3)}$ 。しかしなが ら, インパルス発生器の大型化などに伴い, 実際に発生す る波形にはオーバシュートや振動波が重畳する場合がある。 この主な原因は，電圧発生回路の残留インダクタンスによ るものであることが，経験的に知られていたが，その理論 的取り扱いはあまりなされていないようである(4)。

また，現行の IEC 規格においては発生波形に含まれてい る高周波成分の中で, $0.5 \mathrm{MHz}$ を境として補正を行うのに

\footnotetext{
*九州工業大学工学部

于 804-8550 北九州市戸畑区仙水町 1-1

Kyushu Institute of Technology

1-1, Sensuicho, Tobata-ku, Kitakyushu 804-8550
}

対して, 現在, 改訂作業が行われている IEC60060-1 規格 においては，発生波形に含まれる高周波成分に応じた補正 式を用いて, 波形のオーバシュート分をいわゆる電圧補正 係数 k-factor として補正する方法が提案されている(5)(6)。

しかしながら, 補正式の取り扱いについてはその理論的 根拠が不明であるため, 現時点においても種々の議論がな されている(6)。

このような背景をもとに, 本論文では電圧発生回路にお ける残留インダクタンスを考慮した雷インパルス電圧回路 の発生電圧波形について理論的考察を行い, 振動性あるい は非振動性雷インパルス電圧に対する解析式を導出した。 この結果, これらの解析式を利用して残留インダクタンス の影響を検討することが可能になったので，いくつかの計 算例を示しながら本解析式の有用性について紹介したい(7)。 


\section{2. 回路定数が与えられた場合の発生波形の計算}

〈2.1 回路方程式 インパルス電圧発生回路の残留 インダクタンスを考慮した雷インパルス電圧発生回路の等 価回路例を図 1 に示す。同図に扮いて， $C_{S}$ はインパルス 電圧発生装置の充電用コンデンサの静電容量, $C_{0}$ は供試物 の静電容量を含めた供試物端子間の静電容量, $R_{S}$ と $R_{0}$ は 波形調整用の抵抗である。また， $L_{S}$ はインパルス電圧発生 装置の充電用コンデンサならびに配線などに起因する残留 インダクタンスである。

図 1 において抵抗 $R_{0}$ に流れる電流を $i_{R}$ とすれば次式が 成り立つ。

$$
\begin{aligned}
\frac{d^{3} i_{R}}{d t^{3}} & +\frac{L_{s}+R_{s} R_{0} C_{0}}{L_{s} R_{0} C_{0}} \frac{d^{2} i_{R}}{d t^{2}} \\
& +\frac{C_{S}\left(R_{s}+R_{0}\right)+R_{0} C_{0}}{L_{s} C_{s} R_{0} C_{0}} \frac{d i_{R}}{d t}+\frac{1}{L_{s} C_{s} R_{0} C_{0}} i_{R}=0
\end{aligned}
$$

簡単化のため，(1)式において

$$
\left.\begin{array}{l}
a=\frac{L_{s}+R_{s} R_{0} C_{0}}{L_{s} R_{0} C_{0}}, \\
b=\frac{C_{s}\left(R_{s}+R_{0}\right)+R_{0} C_{0}}{L_{s} C_{s} R_{0} C_{0}} \\
c=\frac{1}{L_{s} C_{s} R_{0} C_{0}}
\end{array}\right\} .
$$

とおくと次式が得られる。

$$
\frac{d^{3} i_{R}}{d t^{3}}+a \frac{d^{2} i_{R}}{d t^{2}}+b \frac{d i_{R}}{d t}+c i_{R}=0
$$

ここで, 定数 $a, b, c$ はいずれも正の実数である。

補足であるが，本論文では電圧発生回路として図 1 のも のを代表例として取り上げたが，どのような回路構成であっ ても, 最終的に (3) 式に示される 3 階線形微分方程式に帰 着できる回路構成であれば，本論文に述べる理論解析結果 を適用できることを付言する。

$\langle\mathbf{2} \cdot \mathbf{2}\rangle$ カルダノの公式による解 $\quad$ (3) 式の一般解は, 三次方程式の解の公式（カルダノの公式）から次のように 求まる。

$$
i_{R}(t)=F e^{x_{1} t}+G e^{x_{2} t}+H e^{x_{3} t}
$$

ここで

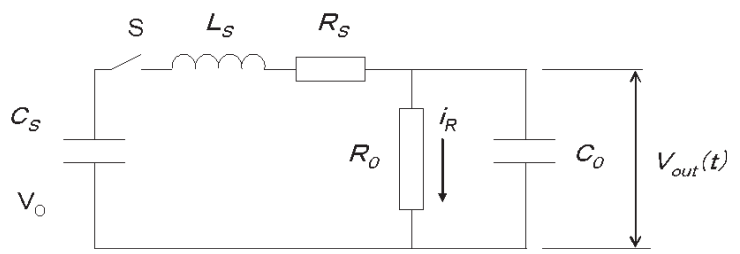

図 1 雷インパルス電圧発生回路の等価回路

Fig. 1. Equivalent circuit for Impulse generator.

$$
\left.\begin{array}{l}
x_{1}=u_{1}+v_{1}-\frac{1}{3} a \\
x_{2}=u_{2}+v_{3}-\frac{1}{3} a \\
x_{3}=u_{3}+v_{2}-\frac{1}{3} a
\end{array}\right\}
$$

ただし，

$$
\begin{aligned}
& u_{1}=\omega_{1} \sqrt[3]{-q+\sqrt{q^{2}+p^{3}}} \\
& u_{2}=\omega_{2} \sqrt[3]{-q+\sqrt{q^{2}+p^{3}}} \\
& \left.u_{3}=\omega_{3} \sqrt[3]{-q+\sqrt{q^{2}+p^{3}}}\right) \\
& v_{1}=\omega_{1} \sqrt[3]{-q-\sqrt{q^{2}+p^{3}}} \\
& v_{2}=\omega_{2} \sqrt[3]{-q-\sqrt{q^{2}+p^{3}}} \\
& \left.v_{3}=\omega_{3} \sqrt[3]{-q-\sqrt{q^{2}+p^{3}}}\right) \\
& \omega_{1}=1 \\
& \omega_{2}=\frac{-1+j \sqrt{3}}{2} \\
& \omega_{3}=\frac{-1-j \sqrt{3}}{2} \\
& p=\frac{3 b-a^{2}}{9} \\
& \left.q=\frac{27 c+2 a^{3}-9 a b}{54}\right\}
\end{aligned}
$$

また，常に次の式が成り立つ。

$$
\frac{1}{C_{0}} \int i_{c} d t=i_{R} R_{0}
$$

初期条件として, $t=0$ で $i_{R}=0, i_{C}=0$ を代入すれば

$$
\begin{aligned}
& F+G+H=0 \cdots \cdots \\
& x_{1} F+x_{2} G+x_{3} H=0 .
\end{aligned}
$$

となる。また， $t=0$ で次式が成り立つ。

$$
\left.L_{S} \frac{d\left(i_{R}+i_{c}\right)}{d t}\right|_{t=0}=V_{0}
$$

これより，次式を得る。

$$
x_{1}^{2} F+x_{2}^{2} G+x_{3}^{2} H=\frac{V_{0}}{L_{s} R_{0} C_{0}}
$$

(11), (12), (14) 式を連立させて解くことにより定数 $F, G, H$ が次のように求まる。

$$
\left.\begin{array}{l}
F=\frac{V_{0}}{L_{S} R_{0} C_{0}} \frac{x_{3}-x_{2}}{\Delta} \\
G=\frac{V_{0}}{L_{S} R_{0} C_{0}} \frac{x_{1}-x_{3}}{\Delta} \\
H=\frac{V_{0}}{L_{S} R_{0} C_{0}} \frac{x_{2}-x_{1}}{\Delta}
\end{array}\right\}
$$

ただし 


$$
\begin{aligned}
\Delta & =\left|\begin{array}{ccc}
1 & 1 & 1 \\
x_{1} & x_{2} & x_{3} \\
x_{1}^{2} & x_{2}^{2} & x_{3}^{2}
\end{array}\right| \\
& =x_{1} x_{2}\left(x_{2}-x_{1}\right)+x_{2} x_{3}\left(x_{3}-x_{2}\right)+x_{3} x_{1}\left(x_{1}-x_{3}\right)
\end{aligned}
$$

また, 発生電圧は抵抗 $R_{0}$ 両端の電圧であるから, 次式で 与えられる。

$$
\begin{aligned}
v_{\text {out }} & =i_{R} R_{0}=\left(F e^{x_{1} t}+G e^{x_{2} t}+H e^{x_{3} t}\right) R_{0} \\
& =V_{1}(t)+V_{2}(t)+V_{3}(t) \cdots \cdots \cdots
\end{aligned}
$$

ここで, 指数関数の指数部の係数 $x_{1}, x_{2}, x_{3}$ は, 3 次方 程式の根の判別式により次のように分類される。

(1) タイプI：1 個の実数と共役複素数

$\mathrm{I}-1$ : 実数が負で共役複素数の実部が負

I-2：実数が負で共役複素数の実部が正

I-3：実数が正

(2) タイプ II : 1 個の実数と実部がこれと同じ值の共 役複素数

II-1：実数が負

II-2：実数が正

(3) タイプ III：1 個の実数とこれとは異なる 2 重根（実 数)

III-1：全ての実数が負

III-2：実数のいずれかが正

(4) タイプIV : 3 重根

IV-1：実数が負

IV-2：実数が正

(5) タイプ V:3 個の異なる実数

$\mathrm{V}-1 ：$ 全ての実数が負

$\mathrm{V}-2$ : いずれかの実数が正

ここで, 判別式 $D$ は $q^{2}+p^{3}$ より導出され, 次式で与え られる。

$$
D=-4 b^{3}+a^{2} b^{2}-4 a^{3} c+18 a b c-27 c^{2}
$$

この分類を表 1 に示す。これらの中でインパルス波形と なるのは，いずれの夕イプとも実数あるいは複素数の実部 が負の場合に限られる。また, 振動性の波形となる場合, そ の周波数は解が共役複素数であることから単一周波数であ ること，さらに虚数部が零（根が実数のみ）の場合には振 動性にはならないことがわかる。

図 2 は，標準雷インパルス波形 $1.2 / 50 \mu \mathrm{s}$ を得るために， $C_{S}=0.02 \mu \mathrm{F}, C_{0}=5000 \mathrm{pF}, R_{S}=104 \Omega, R_{0}=2641 \Omega$ とし， $V_{0}=1 \mathrm{pu}, L_{S}=100 \mu \mathrm{H}$ とした時の波形を，(17) 式 を用いて計算した。これを実線で示す。また，図 2 の破線 は比較のため標準雷インパルス波形を示している。この計 算例では解が夕イプI-1 に属しており，一つは実根，残り 二つは共役複素数の根になっている。また，振動周波数は 単一である。
表 1 回路方程式に対する解の分類

Table 1. Type of the waveform.

\begin{tabular}{|c|c|c|}
\hline \multirow{2}{*}{ Type } & \multicolumn{2}{|c|}{ Distinctions } \\
\cline { 3 - 3 } & $D$ & $q$ \\
\hline I & \multirow{2}{*}{$D<0$} & $q \neq 0$ \\
\cline { 3 - 3 } II & & $q=0$ \\
\hline III & \multirow{2}{*}{$D=0$} & $q=0$ \\
IV & & $q \neq 0$ \\
\hline V & $D>0$ & - \\
\hline
\end{tabular}

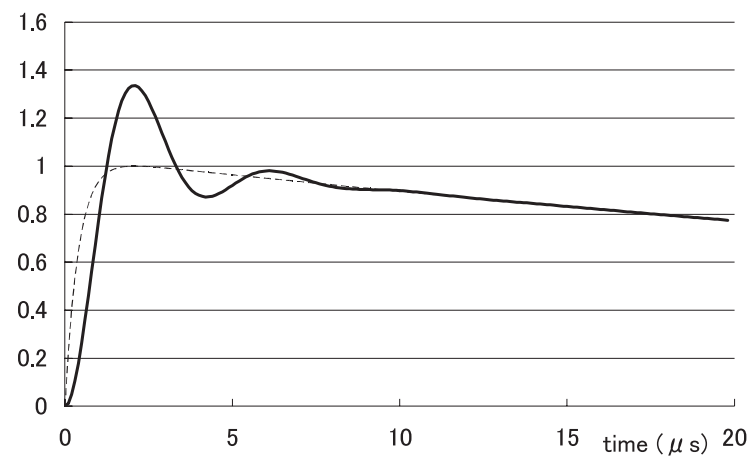

図 2 振動波を含む雷インパルス波形の計算結果 (タイプ I-1)

Fig. 2. Lightning impulse voltage with superposed overshoot or oscillation (Type I-1).

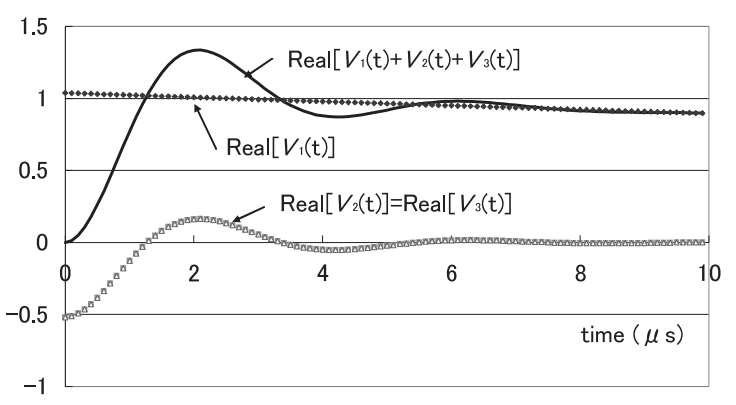

図 3 雷インパルス波形要素の実数部の拡大図 Fig. 3. Real parts of lightning impulse.

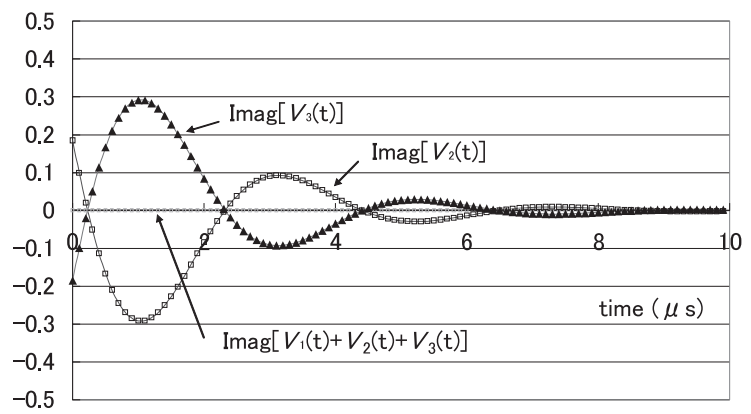

図 4 雷インパルス波形要素の虚数部の拡大図

Fig. 4. Imaginary parts of lightning impulse voltage.

図 3 ならびに図 4 は，(17) 式においてそれぞれの解に対 する実数部と虚数部を分離して示したものである。この中 で, 特に, 実根に対する波形 $V_{1}(\mathrm{t})$ は, 波尾の部分で標準雷 
インパルス波形（図中の破線）に一致していることがわか る。これに対して， $V_{2}(\mathrm{t})$ と $V_{3}(\mathrm{t})$ は，波頭部分に大きく影 響するが，波尾側になると大きく減衰してしまうため波尾 側にはほとんど寄与していないことがわかる。

これから，振動性雷インパルス波形は実数のみを解とす る次式の形で与えられることがわかる。

$$
\begin{aligned}
& v_{\text {out }}=A e^{-\alpha_{1} t}+B e^{-\alpha_{2} t} \sin (\omega t+\theta) . \\
& \text { ただし }, 0<\theta<\pi / 2
\end{aligned}
$$

もし， $\omega=0$ なら，二つの指数関数の組み合わせによる 従来の式(1) (3) と一致する。

$\langle\mathbf{2} \cdot \mathbf{3}\rangle$ 実数根に対する方程式の解（判別式 $D<\mathbf{0} ）$ 実 数で表された方程式 (19) において, 各定数を求めてみる。

初期条件として, $t=0$ で $v_{\text {out }}=0$ であるから, $A+B \sin \theta=$ 0 となり，次式を得る。

$$
v_{\text {out }}(t)=A\left\{e^{-\alpha_{1} t}-e^{-\alpha_{2} t} \frac{\sin (\omega t+\theta)}{\sin \theta}\right\}
$$

ここで, 未知数は $A, \alpha_{1}, \alpha_{2}, \omega, \theta$ の 5 個であり, 全て 実数である。(20) 式において

$$
\begin{aligned}
& v_{1}(t)=A e^{-\alpha_{1} t} \ldots \ldots \ldots \ldots . \\
& v_{2}(t)=-A e^{-\alpha_{2} t} \frac{\sin (\omega t+\theta)}{\sin \theta} .
\end{aligned}
$$

とおき，これらの式をそれぞれ，(3)式に代入し式を整理す ると次の方程式が得られる。

$$
\begin{aligned}
& \alpha_{1}^{3}-a \alpha_{1}^{2}+b \alpha_{1}-c=0 \ldots \ldots \ldots \ldots \\
& 8 \alpha_{2}^{3}-8 a \alpha_{2}^{2}+2\left(a^{2}+b\right) \alpha_{2}+(c-a b)=0 \\
& \omega^{2}=3 \alpha_{2}^{2}-2 a \alpha_{2}+b \ldots \ldots \ldots \ldots \ldots
\end{aligned}
$$

また，次式が成り立つ。

$$
\left.\begin{array}{l}
v_{\text {out }}=\frac{1}{C_{0}} \int i_{c} d t \\
i_{c}=C_{0} \frac{d v_{\text {out }}}{d t}
\end{array}\right\}
$$

初期条件として， $t=0$ で $i_{c}=0$ であるから，これを(20) 式，ならびに(26) 式に代入すると次式が得られる。

$$
\tan \theta=\frac{\omega}{\alpha_{2}-\alpha_{1}} .
$$

また, $t=0$ で(13) 式が成り立つから, 次式が得られる。

$$
\begin{aligned}
A= & \frac{R_{0}}{\alpha_{2}-\alpha_{1}-\omega \cot \theta+R_{0} C_{0}\left(\alpha_{1}^{2}-\alpha_{2}^{2}+\omega^{2}+2 \alpha_{2} \omega \cot \theta\right)} \\
& \times \frac{V_{0}}{L_{s}} \ldots \ldots \ldots \ldots \ldots \ldots \ldots \ldots \ldots \ldots \ldots \ldots \ldots \ldots \ldots \ldots \ldots \ldots \ldots \ldots \ldots
\end{aligned}
$$

よって,これらの值を代入すれば電圧波形は (20) 式で計 算できる。なお，(23) 式は独立变数 $\alpha_{1}$ のみの関数である。 また，(24) 式は独立変数 $\alpha_{2}$ のみの関数である。これに対し て, (25) 式より $\omega$ は $\alpha_{2}$ の関数として, また, (27) 式ならび に(28) 式は， $\alpha_{1}$ と $\alpha_{2}$ の関数として計算できる。一方， $\alpha_{1}$
と $\alpha_{2}$ は定数 $a, b, c$ によって決まる。すなわち，オーバ シュートあるいは振動波を含む雷インパルス電圧は，4つ

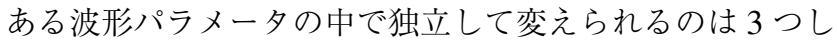
かないことになる。

\section{3. 波形パラメータの計算}

単一の周波数を持つ振動性雷インパルス電圧の波形パラ メータには以下のものがある。

(1) 波高值 $V_{p}$

(2) 波頭長 $T_{1}$

（3） 波尾長 $T_{2}$

(4) 規約原点 $O$

(5) 周波数 $f$

(6) オーバシュート率 $\delta$

（7） 減衰率 $\alpha_{1}$ （既出）

（8） 滅衰率 $\alpha_{2}$ （既出）

これらの中で，波頭長と波尾長については，IEC60060-1 改定案 ${ }^{(6)}$ では記録波形（recorded curve）, 基本波形（base curve）ならびに試験電圧波形（test voltage curve）に分け て検討を行っている。すなわち, 改定案では電圧補正係数 $\mathrm{k}$-factor を考慮した試験電圧波形について波頭長と波尾長 を定義しているが，現行の規格では基本波形に対してこれ らが定義されている。

ここでは，記録波形について，これらを計算してみる。 発生電圧が最大となる時間 $t_{m}$ は $d v_{\text {out }} / d t=0$ より, 次の ようになる。

$$
\alpha_{1} e^{-\alpha_{1} t_{m}}-e^{-\alpha_{2} t_{m}}\left(\left\{\omega+\frac{\left(\alpha_{2}-\alpha_{1}\right) \alpha_{2}}{\omega}\right\} \sin \omega t_{m}+\alpha_{1} \cos \omega t_{m}\right)=0
$$

この式を数值的に解いて求まる $t_{m}$ を (19) 式に代入すれ ば波高值 $V_{p}$ は次のようになる。

$$
\begin{aligned}
V_{p} & =v_{\text {out }}\left(t_{m}\right) \\
& =A\left\{e^{-\alpha_{1} t_{m}}-e^{-\alpha_{2} t_{m}} \frac{\sin \left(\omega t_{m}+\theta\right)}{\sin \theta}\right\}
\end{aligned}
$$

次に，波頭に扔いて，波高值の $30 \%$ に達する時間を $t_{30 \%}$ とすれば次式が得られる。

$$
0.3 V_{p}=v_{\text {out }}\left(t_{30 \%}\right) \quad \text { ただし, } t_{30 \%}<t_{m}
$$

波頭において波高值の $90 \%$ に達する時間を $t_{90 \%}$ とすれば 次式が得られる。

$$
0.9 V_{p}=v_{\text {out }}\left(t_{90 \%}\right) \text { ただし } t_{90 \%}<t_{m}
$$

波尾において，50\%に達する時間を $t_{50 \%}$ とすれば次式が得 られる。

$$
0.5 V_{p}=v_{\text {out }}\left(t_{50 \%}\right) \quad \text { ただし, } t_{50 \%}>t_{m}
$$

波頭長 $T_{1}$ と波尾長 $T_{2}$ は定義により，次式で計算される。

$$
T_{1}=\frac{10}{6}\left(t_{90 \%}-t_{30 \%}\right)
$$




$$
\begin{aligned}
T_{2} & =t_{50 \%}-t_{0} \\
& =\left(t_{50 \%}-t_{30 \%}\right)+\frac{t_{90 \%}-t_{30 \%}}{2} \\
& =\frac{t_{90 \%}-3 t_{30 \%}}{2}+t_{50 \%} \cdots \cdots
\end{aligned}
$$

また，計算上の原点と規約原点 $O^{\prime}$ との時間差は次のよう になる。

$$
t_{0}=\frac{3 t_{30 \%}-t_{90 \%}}{2}
$$

周波数については (25) 式から次のように求まる。

$$
f=\frac{\sqrt{3 \alpha_{2}^{2}-2 a \alpha_{2}+b}}{2 \pi}
$$

オーバシュート率については, 振動がない場合の波形 (文 献 (6) では Base curve と称している) との比較により，(30) 式を用いて計算できる。

\section{4. 計 算 例}

図 5 ならびに図 6 は，標準雷インパルスとの比較を行う ため，前述の回路定数を用いて， $V_{0}=1 \mathrm{pu}$ とし， $L_{S}$ をそ れぞれ $20 \mu \mathrm{H}, 50 \mu \mathrm{H}$ とした場合について，(20) 式より電 圧波形を計算した結果を示す。また，比較のため，標準雷 インパルス波形を図中に破線で示した。

表 2 には同じ回路定数に対し $L_{S}$ のみを変化させた時の 波形パラメータの相互比較例を示す。

これらの計算結果から, 標準雷インパルス電圧波形との 比較において次のことが言える。

（1）残留インダクタンスは波頭部に大きく影響するが, 波尾への影響は少ない。

（2）波形については，残留インダクタンスが大きくな るにつれてオーバシュート率 $\delta$ が大きくなる。

（3）この結果，オーバシュート率 $\delta$ が大きくなると，波 尾長は短く計算されることになる。

（4）波高值となる時間 $t_{m}$ は残留インダクタンスが大き くなるにつれて長くなるが，残留インダクタンスの大小に より標準波形よりも短くも長くもなる。

（5）波頭長についても残留インダクタンスの大小によ り標準波形よりも短くも長くもなる。

（6）周波数は残留インダクタンスが大きくなるにつれ て低下する。

（7）規約原点は残留インダクタンスが大きくなるにつ れて，原点からプラス側に移動する。

このように，残留インダクタンスは波頭部分に大きく影 響するが，波尾にはあまり影響しないことがわかる。なお， 波形表示については波形の定義により，数值が大きく異な るため注意が必要である。

このように, 今回導出した式を用いて残留インダクタン スが波形に及ぼす影響を解析できる。また同時に，オーバ シュートなどの種々の波形パラメータの評価を行えること がわかる。

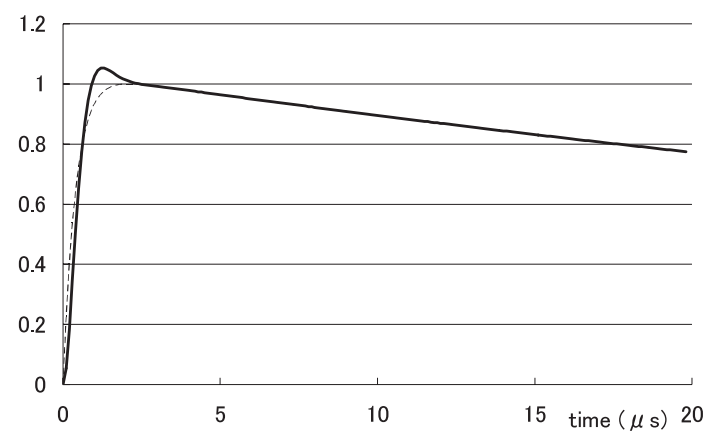

図 5 標準雷インパルス波形との比較

Fig. 5. Comparison with overshoot waveform and standard lightning impulse $(L s=20 \mu \mathrm{H}, \delta=5.3 \%$, Type: I-1).

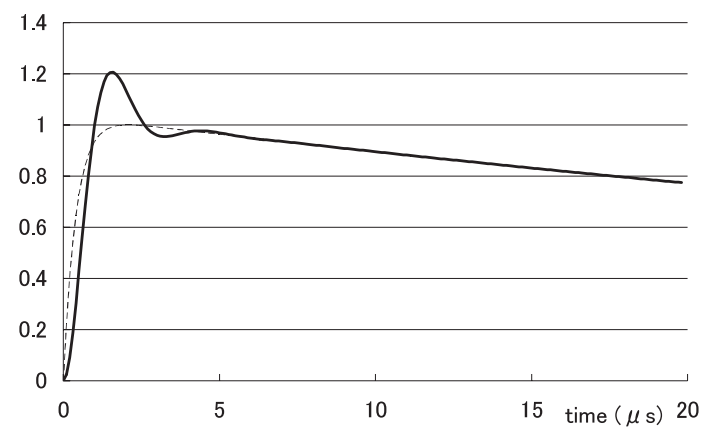

困 6 他の計算例

Fig. 6. Another example $\left(L_{s}=50 \mu \mathrm{H}, \delta=20.7 \%\right.$, Type: I-1).

表 2 波形パラメータの計算例

Table 2. Summary of calculation results $\left(C_{S}=0.02 \mu \mathrm{F}\right.$, $C_{0}=5000 \mathrm{pF}, R_{S}=104 \Omega, R_{0}=2641 \Omega$ ).

\begin{tabular}{|c|c|c|c|c|c|}
\hline \multirow{2}{*}{} & \multicolumn{5}{|c|}{ Residual inductance $L_{S}(\mu \mathrm{H})$} \\
\cline { 2 - 6 } & 0 & 20 & 50 & 100 & 200 \\
\hline$T_{1}(\mu \mathrm{s})$ & 1.2 & 0.87 & 1.13 & 1.50 & 2.06 \\
\hline$T_{2}(\mu \mathrm{s})$ & 50 & 45.9 & 36.6 & 29.9 & 24.1 \\
\hline$t_{m}(\mu \mathrm{s})$ & 2.09 & 1.26 & 1.56 & 2.07 & 2.84 \\
\hline$V_{p}(\mathrm{p} \mathrm{u})$ & 1 & 1.053 & 1.21 & 1.36 & 1.45 \\
\hline$\delta \quad(\%)$ & - & 5.3 & 20.7 & 33.6 & 44.7 \\
\hline$f(\mathrm{k} \mathrm{Hz})$ & - & 387 & 318 & 239 & 174 \\
\hline$O^{\prime}, t_{0}(\mu \mathrm{s})$ & -0.22 & 0.01 & 0.11 & 0.11 & 0.31 \\
\hline$t_{30 \%}(\mu \mathrm{s})$ & 0.14 & 0.28 & 0.64 & 0.64 & 0.93 \\
\hline$t_{90 \%}(\mu \mathrm{s})$ & 0.86 & 0.80 & 1.54 & 1.54 & 2.16 \\
\hline$t_{50 \%}(\mu \mathrm{s})$ & 49.4 & 45.9 & 29.8 & 29.9 & 24.4 \\
\hline Type (Table 1$)$ & $(\mathrm{III}-1)$ & $\mathrm{I}-1$ & $\mathrm{I}-1$ & $\mathrm{I}-1$ & $\mathrm{I}-1$ \\
\hline
\end{tabular}

\section{5. まとめ}

インパルス発生回路に残留インダクタンスが存在する場 合の発生波形について解析式を導出し，いくつかの計算例 を示した。これらの結果をまとめると次のようになる。

（1）振動性雷インパルス電圧に対する電圧波形は (20) 
式で与えられる。

（2）振動性インパルス電圧の波形パラメータである波 高值（オーバシュート率），波高点となる時間，波頭長，波 尾長, 規約原点, 振動周波数ならびに減衰定数について解 析式を導出した。

（3）振動性インパルス波形は波高值（オーバシュート 率)，波頭長，波尾長，周波数の 4 つの波形パラメータで 表されるが，これらの中で独立して変えられるのは 3 つで ある。

（4）残留インダクタンスは波頭部へ大きく影響するが, 波尾への影響は少ない。

（5）今回の理論式は，例えばIEC 規格の改定案におい て議論されている記録波形と試験波形に対する周波数補正 を含む波形パラメータの評価についての議論にも活用がで きることを計算例で示した。

（6）複素解である (17) 式を用いれば，振動性の波形以 外にも解析が可能であり，汎用性のある解析式とすること ができる。

なお，今回の解析式の導出方法はインパルス波形を発生 させることのできる他の回路例 ${ }^{(3)}$ についても同様に展開で きる。

また, 今回の解析式の応用例には, 種々のものが考えら れる。例えば，大型インパルス電圧発生器などでは残留イ ンダクタンスを測定することは困難なことが多いが，今回 の式を用いることにより，実測波形から残留インダクタン スを推定することができる。

最後に, 図 1 においてインパルス電圧発生器のコンデン サの容量 $C_{S}$, 負荷側コンデンサの容量 $C_{0}$, ならびに発生 波形 $T_{1}, T_{2}$ やその他の波形パラメータが与えられた場合 の抵抗 $R_{S}, R_{0}$ ならびにインダクタンス $L_{S}$ の計算は逆問題 として解析可能である。これについては別の機会に紹介し たい。

\section{謝 辞}

本稿をまとめるにあたり，大変有益かつ貴重なご助言を

頂いた東京大学名誉教授河野照哉先生, 河村達雄先生, 横 浜国立大学西村誠介先生, 九州工業大学匹田政幸先生なら びに大塚信也先生に深く感謝いたします。

(平成 19 年 1 月 25 日受付，平成 19 年 6 月 8 日再受付)

\section{文献}

（1）法貴四郎・藤 幸生：「衝撃電圧発生器の回路定数の決定」, 電気学 会雑誌, Vol.61, No.637, pp.422-424 (1941-8)

（2）法貴四郎・藤 幸生：「衝撃電圧発生器の発生波形の算定」, 電気学 会雑誌, Vol.61, No.639, pp.507-508 (1941-10)

(3) Handbook for High Voltage Tests, pp.69-81, IEE Japan (1983) (in Japanese) 高電圧試験ハンドブック,pp.69-81, 電気学会 (1983)

(4) S. Sato, T. Harada, T. Ebana, H. Hoshi, and S. Sakaguchi: "Automatic Determination of the Circuit Constants Fulfilling the Given Impulse Time Parameters", IEEE Trans. FM, Vol.126, No.9, pp.887-894 (2006-9) (in Japanese) 里 周二・原田達哉・江花崇雄・星 秀和・坂口寿美子：「時間パラ メータが与えられた場合の雷インパルス電圧発生回路素子定数の決 定」,電学論 A, 126, 9, pp.887-894 (2006-9)

(5) J. Hallstrom, S. berlijn, M. Gamlin, F. Garnacho, E. Gockenbach, T. Kato, Y $\mathrm{Li}$, and J. Rungis: "Applicability of different implementations of K-factor filtering schemes for the revision of IEC60060-1 and 2", Internatinal Symposium on High Voltage Engineering, Paper No.B-32, pp.1-6, Beijing, China (2005)

(6) IEC 60060-1 Ed.3.0 High voltage test techniques Part 1 General definitions and test requirements (2007)

7 S. Matsumoto: "Influence of the residual inductance for the generation of the lightning impulse voltage", 2007 National Convention Record IEE Japan, No.7-115 (2007-3) (in Japanese)

松本 聡:「雷インパルス電圧発生回路の残留インダクタンスが電 圧波形に及ほす影響の理論的検討」, 平成 19 年電気学会全国大会, No.7-115 (2007-3)

松 本

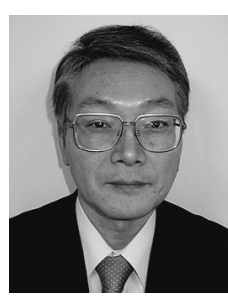

聡（上級会員） 1984 年 3 月東京大学大学院工学研 究科電気工学専攻博士課程修了。工学博士。同年 4 月東芝入社。 2003 年より九州工業大学客員教 授。2007 年より芝浦工業大学工学部教授。IEEE Senior Member 